\title{
ANALISIS FAKTOR-FAKTOR YANG MEMPENGARUHI NET PROFIT MARGIN PERUSAHAAN MANUFAKTUR YANG TERDAFTAR PADA BURSA EFEK INDONESIA
}

\author{
Heri Kurniansyah
}

Akademi Akuntansi dan Manajemen Mitra Lampung JL. ZA Pagar Alam No.07 Gedong Meneng, Rajabasa, Bandar Lampung herikurniansyah@umitra.ac.id

\begin{abstract}
ABSTRAK
Penelitian ini menganalisa pengaruh dari variabel Current Ratio, Working Capital Turnover dan Debt Ratio terhadap Net Profit Margin. Data sekunder yang digunakan dalam penelitian ini laporan keuangan tahunan periode 2011-2015. Jumlah sampel sebanyak 10 perusahaan manufaktur sub sektor farmasi dengan metode Purposive Sampling. Teknik analisis yang digunakan adalah regresi berganda untuk menguji pengaruh beberapa variabel independen terhadap variabel dependen. Hasil penelitian menunjukkan bahwal Current Ratio dan Debt Ratio tidak berpengaruh siginifikan terhadap Net Profit Margin. Sementara Working Capital Turnover berpengaruh positif dan signifikan terhadap Net Profit Margin. Hasil penelitian ini menunjukkan 11,4\% Net Profit Margin dipengaruhi oleh Current Ratio, Working Capital Turnover dan Debt Ratio sedangkan sisanya sebesar 88,6\% dipengaruhi oleh faktor lain.
\end{abstract}

Kata Kunci : Current Ratio, Working Capital Turnover, Debt Ratio, Net Profit Margin

\begin{abstract}
This study analyzes the effect Current Ratio, Working Capital Turnover and Debt Ratio of to Net Profit Margin. Secondary data were obtained from published annual reports of manufacture company that derived from Indonesia Stock Exchange's Website and official website company covering the period of 2011 until 2015. This study used sampel of 10 manufacture company especially pharmacy sub sector taken by Purposive Sampling. Multiple linear regression analysis isused to explain the effect of explanatory several variable to dependent variable. The study found that has no sgnificant effect Current Ratio and Debt Ratio on Net Profit Margin. Meanwhile, Working Capital Turnover is positively related to Net Profit Margin.This study found that 11,4\% Net Profit Margin influenced by Current Ratio, Working Capital Turnover and Debt Ratio while the side of $88,6 \%$ influenced by another factor.
\end{abstract}

Keyword : Current Ratio, Working Capital Turnover, Debt Ratio, Net Profit Margin 


\section{PENDAHULUAN \\ 1.1 Latar Belakang}

Keputusan penting yang dirumuskan pihak manajemen sebuah perusahaan adalah keputusan yang memiliki dampak secara menyeluruh terhadap kondisi keuangan dan pertumbuhan perusahaan. Para pemangku kepentingan baik internal maupun eksternal mempertimbangkan beberapa besaran persentase dari perbandingan beberapa faktor penyokong kegiatan operasional dan pertumbuhan perusahaan. Profitabilitas merupakan kemampuan perusahaan dalam memperoleh laba yang memiliki hubungan terhadap aktivitas penjualan, total aktiva maupun modal (Kadir Abdul, 2012). Analisis rasio keuangan merupakan salah satu metode analisis yang akurat bagi pihak manajemen dalam pengambilan keputusan. Analisis rasio juga dilakukan pihak eksternal user baik kreditur, investor maupun pemerintahan guna pengambilan keputusan yang relevan dengan masing-masing kepentingan. Aspek-aspek keuangan yang secara umum diklasifikasikan meliputi aspek likuiditas, aspek efesiensi, aspek solvabilitas dan aspek profitabilitas (Keuwn Scott, 2008).

Aspek likuiditas merupakan rasio-rasio yang digunakan untuk mengukur kemampuan perusahaan dalam memmbayar hutang jangka pendek yang jatuh tempo. Aspek likuditas terdiri dari current ratio, cash ratio, dan acid ratio (Munawir, 2004).

Aspek aktivitas atau efesiensi merupakan aspek yang menunjukkan tingkat efesiensi operasional perusahaan dalam menggunakan sumber-sumber (resources) yang ada dalam pengendaliannya. Aspek ini meliputi inventory turnover, receivable turnover, total asset turnover dan working capital turnover.

Aspek leverage atau solvabilitas yang berhubungan dnegan pembiayaan utang perusahaan merupakan kemampuan perusahaan dalam menggunakan aktiva atau dana yang mempunyai beban tetap (fixed cost assets or funds) dalam memperbesar tingkat pendapatan bagi perusahaan (Syamsuddin, 2001). Debt ratio merupakan rasio hutang yang digunakan untuk membandingkan antara total hutang dengan total aktiva (Kasmir, 2008).

Aspek profitabilitas merupakan aspek yang menggambarkan bagaimana efektifnya perusahaan dalam mengelola sumber daya dan sumber dana untuk menghasilkan laba (Keuwn, 2005). Dalam penelitian ini aspek profitabilitas perusahaan diukur menggunakan perhitrungan rasio Net Profit Margin yang merupakan perbandingan antara jumlah laba bersih perusahaan dengan jumlah penjualan per periode perusahaan.

Kondisi dimana masih terdapat beberapa perusahaan manufaktur sub sektor farmasi yang masih memiliki nilai Net Profit Margin dalam batas minimum standar rata-rata industri. Perhitungan mengenai tingkat laba yang akan diperoleh dengan tingkat penjualan yang dilakukan harus benarbenar efesien, sehingga faktor-faktor yang mempengaruhi Net Profit Margin perusahaan menjadi perhatian utama dalam pembangunan dan pengembangan industri manufaktur ini. Hal inilah yang melatarbelakangi penelitian ini untuk mengambil judul penelitian menagenai "Analisis FaktorFaktor yang Mempengaruhi Net Profit Margin Perusahaan Manufaktur yang terdaftar di Bursa Efek Indonesia Periode 2011-2015 “

\subsection{Rumusan Masalah}

Berdasarkan latar belakang yang telah dikemukakan maka rumusan masalah dalam penelitian ini adalah sebagai berikut :

1. Apakah Current Ratio, Working Capital Turnover dan Debt Ratio berpengaruh secara simultan terhadap Net Profit Margin perusahaan manufaktur yang terdaftar di Bursa Efek Indonesia Periode 2011-2015? 
2. Apakah Current Ratio berpengaruh secara parsial terhadap Net Profit Margin perusahaan manufaktur yang terdaftar di Bursa Efek Indonesia Periode 2011-2015?

3. Apakah Working Capital Turnover berpengaruh secara parsial terhadap Net Profit Margin perusahaan manufaktur yang terdaftar di Bursa Efek Indonesia Periode 2011-2015?

4. Apakah Debt Ratio berpengaruh secara parsial terhadap Net Profit Margin perusahaan manufaktur yang terdaftar di Bursa Efek Indonesia Periode 2011-2015?

\subsection{Tujuan Penelitian}

Berdasarkan rumusan masalah dalam penelitian ini maka tujuan penelitian adalah sebagai berikut :

1. Untuk mengetahui pengaruh Current Ratio, Working Capital Turnover dan Debt Ratio secara simultan terhadap Net Profit Margin perusahaan manufaktur yang terdaftar di Bursa Efek Indonesia Periode 2011-2015.

2. Untuk mengetahui pengaruh Current Ratio secara parsial terhadap Net Profit Margin perusahaan manufaktur yang terdaftar di Bursa Efek Indonesia Periode 2011-2015.

3. Untuk mengetahui pengaruh Working Capital Turnover secara parsial terhadap Net Profit Margin perusahaan manufaktur yang terdaftar di Bursa Efek Indonesia Periode 2013-2017.

4. Untuk mengetahui pengaruh Debt Ratio secara parsial terhadap Net Profit Margin perusahaan manufaktur yang terdaftar di Bursa Efek Indonesia Periode 2011-2015.

\section{LANDASAN TEORI}

Analisis rasio keuangan adalah Future Oriented atau berorientasi dengan masa depan, artinya bahwa dengan analisa ratio keuangan bisa digunakan sebagai alat utk meramalkan keadaan keuangan serta hasil usaha dimasa mendatang. Dengan angka-angka rasio historis atau kalo memungkinkan dengan angka rasio industri (yang dilengkapi dengan data lainnya) bisa digunakan sebagai dasar utk penyusunan laporan keuangan yang diproyeksikan yang merupakan salah satu bentuk perencanaan keuangan perusahaan (S. Munawir, 2001).

\subsection{Rasio Likuditas}

Perhitungan rasio likuiditas memberikan cukup banyak manfaat bagi berbagai pihak yang berkepentingan terhadap perusahaan. Berikut ini adalah beberapa tujuan dan manfaat yang dapat dipetik dari hasil rasio likuiditas adalah mengukur kemampuan perusahaan membayar kewajiban atau utang yang segera jatuh tempo pada saat ditagih, mengukur kemampuan perusahaan membayar kewajiban jangka pendek dengan aktiva lancar secara keseluruhan, mengukur kemampuan perusahaan membayar kewajiban jangka pendek dengan aktiva lancar tanpa memperhitungkan sediaan atau piutang dan mengukur atau membandingkan antara jumlah sediaan yang ada dengan modal kerja perusahaan (Kasmir, 2012). Rasio Lancar (Current Ratio) merupakan rasio yang menunjukan sejauh mana aktiva lancar menutupi kewajiban-kewajiban lancar. Semakin besar perbandingan aktiva lancar dengan utang lancar semakin tinggi kemampuan perusahaan menutupi kewajiban jangka pendeknya..

\subsection{Rasio Aktivitas dan Efesiensi}

Rasio Aktivitas adalah rasio untuk menilai kemampuan perusahaan dalam melaksanakan aktivitas sehari-hari atau kemampuan perusahaan dalam penjualan, penagihan piutang maupun pemanfaatan aktiva yang dimiliki (Munawir, 2002). Rasio aktivitas adalah rasio yang menggambarkan aktivitas yang dilakukan perusahaan dalam menjalankan operasinya baik dalam kegiatan penjualan, pembelian dan kegiatan lainnya (Sofyan Syafri Harahap, 2009). Working Capital Turnover (WCT) adalah rasio yang digunakan untuk mengukur berapa kali dana yang ditanamkan dalam modal kerja berputar dalam satu periode atau berapa penjualan yang dapat dicapai oleh setiap modal kerja yang diinginkan (Kasmir, 2009). 


\subsection{Rasio Leverage}

Rasio leverage adalah mengacu pada penggunaan asset dan sumber dana oleh perusahaan dimana dalam penggunaan asset atau dana tersebut perusahaan harus mengeluarkan biaya tetap atau beban tetap (Sutrisno, 2001). Rasio leverage merupakan kemampuan perusahaan untuk menggunakan aktiva atau dana yang mempunyai beban tetap (fixed cost assets or funds) yang gunanya untuk memperbesar tingkat penghasilan (return) bagi pemilik perusahaan (Lukman Syamsuddin, 2009). Debt ratio merupakan rasio utang yang digunakan untuk mengukur perbandingan antara total hutang dengan total aktiva. Dengan kata lain, seberapa besar aktiva perusahaan dibiayai oleh hutang atau seberapa besar hutang perusahaan berpengaruh terhadap pengelolaan aktiva (Kasmir, 2008).

\subsection{Rasio Profitabilitas}

Profitablitas atau kemampuan memperoleh laba adalah suatu ukuran dalam persentase yang digunakan untuk menilai sejauh mana perusahaan mampu menghasilkan laba pada tingkat yang dapat diterima. Rasio profitabilitas merupakan rasio untuk menilai kemampuan perusahaan dalam mencari keuntungan. Rasio ini juga memberikan ukuran tingkat efektivitas manajemen suatu perusahaan (Kasmir, 2013). Net Profit Margin adalah suatu rasio yang mengukur keuntungan netto per rupiah penjualan. Net Profit Margin (NPM), merupakan rasio yang digunakan untuk mengukur margin laba atas penjualan, rasio ini akan menggambarkan penghasilan bersih perusahaan berdasarkan total penjualan. Pengukuran rasio dapat dilakukan dengan cara membandingkan laba bersih setelah pajak dengan penjualan bersih (Bambang Riyanto, 2013).

\section{METODOLOGI}

\subsection{Populasi}

Populasi dari penelitian ini adalah seluruh perusahaan manufaktur sub sektor bahan kimia dan farmasi yang terdaftar di Bursa Efek Indonesia tahun 2011-2015 sebanyak 18 perusahaan.

\subsection{Sampel}

Teknik pengambilan sampel dalam penelitian ini menggunakan metode purposive samling yaitu pengambilan sampel dilakukan melalui penetapan kriteria tertentu. Jumlah sampel penelitian ini adalah sebanyak 10 perusahaan manufaktur sub sektor farmasi yang terdaftar di Bursa Efek Indonesia tahun 2011-2015.

\subsection{Metode Analisis Data}

\subsubsection{Uji Asumsi Klasik}

1. Uji Normalitas

Uji normalitas bertujuan untuk menguji apakah dalam model regresi, variabel independen dan dependen keduanya mempunyai distribusi normal atau tidak. Model regresi yang baik adalah memiliki distribusi data normal (Elizar Arief, 2014).

2. Uji Multikolinearitas

Uji multikolinearitas bertujuan untuk melihat model regresi terdapat korelasi yang tinggi atau sempurna antara variabel independen. Uji multikolinearitas ini dilakukan pada model rgresi linear berganda yang memiliki jumlah variabel independen lebih dari satu, dengan tujuan mendqapatkan nilai variabel-variabel yang ortogal (Elizar Arief, 2014).

3. Uji Heterkodestisitas

Uji heterokedastisitas bertujuan untuk menguji apakah dalam model regresi terjadi ketidaksamaan varian dari residual pengamatan kepengamatan lain (Ghozali, 2011).

4. Uji Autokorelasi

Uji autokorelasi bertujuan untuk menguji apakah model regresi linear ada korelasi anatara penggangu pada periode t pada kesalahan penggangu pada periode t-1 (Ghozali, 2011). 


\subsubsection{Analisis Kuantitatif}

1. Uji Regresi Linear Berganda

$Y=a+b_{1} x_{1}+b_{2} x_{2}+b_{3} x_{3}+e$

Keterangan :

$\mathrm{Y}=$ Net Profit Margin (NPM)

$\mathrm{a}=$ Konstanta

$\mathrm{x}_{1}=$ Current Ratio (CR)

$\mathrm{x}_{2}=$ Working Capital Turnover (WCT)

$\mathrm{x}_{3}=$ Debt Ratio (DR)

e $=$ Standard Error

\section{Uji T (Parsial)}

Pengujian untuk maisng-masing variabel independen meliputi current ratio, working capital turnover dan debt ratio terhadap variabel dependen net profit margin menggunakan regresi parsial (Uji T).

\section{Uji F (Simultan)}

Uji $\mathrm{F}$ digunakan untuk menguji hipotesis nol bahwa koefisien determinasi majemuk dalam populasi, R 2 , sama dengan nol. Uji signifikansi meliputi pengujian signifikansi persamaan regresi secara keseluruhan serta koefisien regresi parsial spesifik. Uji keseluruhan dapat dilakukan dengan menggunakan statistik F Statistik uji ini mengikuti distribusi F dengan derajat kebebasan k dan (nk-1) (Malhotra, 2006).

\section{PEMBAHASAN}

\subsection{Analisis Statistik Deskriptif}

1. Variabel Current Ratio (X1) mempunyai nilai rata-rata (mean) sebesar 205,08 dengan nilai minimum sebesar 196 dan nilai maksimal sebesar 213, dengan demikian dapat disimpulkan bahswa secara statistik nilai Current Ratio 10 perusahaan manufaktur sub sektor farmasi yang terdaftar di Bursa Efek Indonesia periode 2011-2015 berada dalam standar batas minimum industri.

2. Variabel Working Capital Turnover (X2) mempunyai nilai rata-rata (mean) sebesar 603,22 dengan nilai minimum sebesar 580 dan nilai maksimal sebesar 628, dengan demikian dapat disimpulkan bahswa secara statistik nilai Working Capital Turnover 10 perusahaan manufaktur sub sektor farmasi yang terdaftar di Bursa Efek Indonesia periode 2011-2015 berada dalam standar batas minimum industri.

3. Variabel Debt Ratio (X3) mempunyai nilai rata-rata (mean) sebesar 36,16 dengan nilai minimum sebesar 32 dan nilai maksimal sebesar 40, dengan demikian dapat disimpulkan bahswa secara statistik nilai Debt Ratio 10 perusahaan manufaktur sub sektor farmasi yang terdaftar di Bursa Efek Indonesia periode 2011-2015 berada dalam standar batas minimum industri.

4. Variabel Net Profit Margin (Y) mempunyai nilai rata-rata (mean) sebesar 23,40 dengan nilai minimum sebesar 20 dan nilai maksimal sebesar 30, dengan demikian dapat disimpulkan bahswa secara statistik nilai Net Profit Margin 10 perusahaan manufaktur sub sektor farmasi yang terdaftar di Bursa Efek Indonesia periode 20112015 berada dalam standar batas minimum industri. 
1. Hasil Uji Normalitas

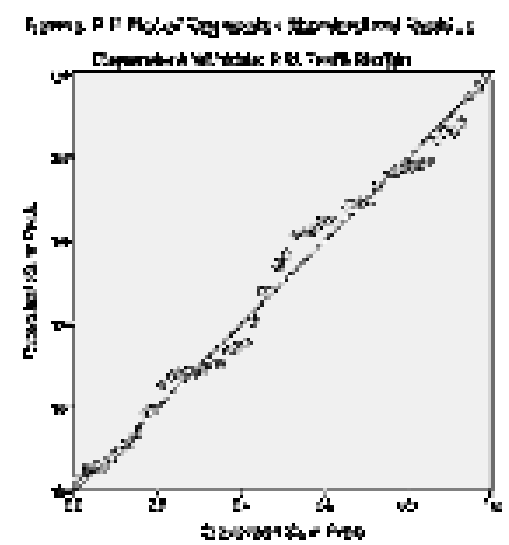

Sumber : Data yang Diolah

Tampilan grafik Normal P-P Plot of Regression Standardized Residual yang menunjukkan sebaran titik mengikuti arah garis normalitas, hal ini menunjukkan bahwa model regresi layak digunakan dalam penelitian ini karena telah memenuhi asumsi normalitas.

2. Hasil Uji Multikolinearitas

\begin{tabular}{|c|c|c|c|}
\hline \multicolumn{4}{|c|}{ Coefficients $^{\mathrm{a}}$} \\
\hline \multirow[b]{2}{*}{ Model } & & \multicolumn{2}{|c|}{ Collinearity Statistics } \\
\hline & & Tolerance & VIF \\
\hline \multirow[t]{4}{*}{1} & (Constant) & & \\
\hline & $\begin{array}{l}\text { Current } \\
\text { Ratio }\end{array}$ & 983 & 1,017 \\
\hline & $\begin{array}{l}\text { Working } \\
\text { Capital } \\
\text { Turnover }\end{array}$ & ,934 & 1,071 \\
\hline & $\begin{array}{l}\text { Debt } \\
\text { Ratio }\end{array}$ & ,921 & 1,085 \\
\hline
\end{tabular}

a. Dependent Variable: Net Profit Margin

Sumber : Data yang Diolah

Nilai tollerance dari keempat variabel independen berada diatas 0,10 dan VIF kurang dari 10. Dengan demikian dapat dismpulkan bahwa model regresi dalam penelitian ini layak untuk digunakan karena tidak terdapat masalah multikolinearitas.

3. Hasil Uji Heterokedastisitas

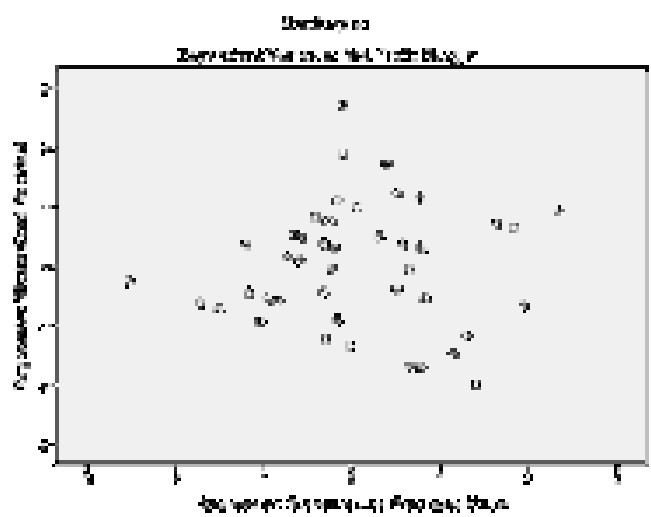

Sumber : Data yang Diolah 
Data yang ditampilkan dalam bentuk sebaran titik-titik secara merata diatas dan dibawah garis nol, tidak mengumpul pada satu tempat dan tidak membentuk pola terntentu menunjukkan bahwa model regresi yang digunakan dalam penelitian ini layak digunakan karena tidak terdapat masalah heterokedastisitas.

4. Hasil Uji Autokorelasi

\begin{tabular}{|l|r|r|r|r|r|}
\hline Model & $\mathrm{R}$ & $\mathrm{R}$ Square & $\begin{array}{c}\text { Adjusted R } \\
\text { Square }\end{array}$ & $\begin{array}{c}\text { Std. Error of the } \\
\text { Estimate }\end{array}$ & Durbin-Watson \\
\hline 1 &, $410^{\mathrm{a}}$ &, 168 &, 114 & 2,559 & 1,495 \\
\hline
\end{tabular}
a. Predictors: (Constant), Debt Ratio, Current Ratio, Working Capital Turnover
b. Dependent Variable: Net Profit Margin

Sumber : Data yang Diolah

Nilai Durbin Watson yang diperoelh model regressi ini adalah sebesar 1,495. Sehinggaa (4-d) $>$ du sebesar 1,7214 hal ini menunjukkan bahwa model regresi dalam penelitian ini layak digunakan karena tidak terjadi masalah autokorelasi.

\subsection{Regresi Linear Berganda}

\begin{tabular}{|c|c|c|c|}
\hline \multicolumn{4}{|c|}{ Coefficients $^{a}$} \\
\hline \multirow{2}{*}{\multicolumn{2}{|c|}{ Model }} & \multicolumn{2}{|c|}{ Unstandardized Coefficients } \\
\hline & & B & $\begin{array}{l}\text { Std. } \\
\text { Error }\end{array}$ \\
\hline \multirow[t]{4}{*}{1} & (Constant) & $-55,114$ & 29,267 \\
\hline & Current Ratio &, 075 & ,070 \\
\hline & $\begin{array}{l}\text { Working Capital } \\
\text { Turnover }\end{array}$ & 090 & ,045 \\
\hline & Debt Ratio & ,250 & ,192 \\
\hline
\end{tabular}

a. Dependent Variable: Net Profit Margin

Sumber : Data yang Diolah

1. Konstanta sebesar $-55,114$ menunjukkan bahwa jika variabek-variabel independen (CR, WCT dan DR) diasumsikan tidak mengalami perubahan atau konstan maka nilai NPM adalah sebesar 55,114\%.

2. Koefesien variabel $\mathrm{CR}$ sebesar 0,075 hal ini berarti setiap kenaikan $\mathrm{CR}$ sebesar $1 \%$ akan menyebabkan kenaikan NPM sebesar 7,5\%.

3. Koefesien variabel WCT sebesar 0,090 hal ini berarti setiap kenaikan WCT sebesar $1 \%$ akan menyebabkan kenaikan NPM sebesar 9\%.

Koefesien variabel DR sebesar 0,250 hal ini berarti setiap kenaikan DR sebesar 1\% akan menyebabkan kenaikan NPM sebesar 25\%.

\subsection{Uji Hipotesis}

\subsubsection{Hasi Uji T (Parsial)}

\begin{tabular}{|ll|r|r|}
\hline \multicolumn{4}{|c|}{ Coefficients $^{\mathbf{a}}$} \\
\hline Model & $\mathrm{t}$ & Sig. \\
\hline 1 & (Constant) & $-1,883$ &, 066 \\
& Current Ratio & 1,070 &, 290 \\
& Working Capital Turnover & 2,994 &, 042 \\
& Debt Ratio & 1,301 &, 200 \\
\hline
\end{tabular}

a. Dependent Variable: Net Profit Margin

Sumber : Data yang Diolah 
1. Secara parsial $\mathrm{t}$ hitung Current Ratio diperoleh sebesar 1,070 yang lebih kecil dibandingkan dengan nilai t tabel dan nilai signifikansi sebesar 0,290 lebih besar diatas 0,05. Hal ini menunjukkan bahwa perubahan yang terjadi pada variabel Current Ratio tidak berpengaruh terhadap kondisi variabel Net Profit Margin. Jadi, hipotesis awal yang diajukan yaitu "Current Ratio berpengaruh secara parsial terhadap Net Profit Margin perusahaan manufaktur yang terdaftar di Bursa Efek Indonesia Periode 2011-2015” ditolak karena nilai signifikasi yang lebih besar dari 0,05 .

2. Secara parsial t hitung Woring Capital Turnover diperoleh sebesar 2,994 yang lebih besar dibandingkan dengan nilai t tabel dan nilai signifikansi sebesar 0,042 lebih kecildari 0,05. Hal ini menunjukkan bahwa perubahan yang terjadi pada variabel Working Capital Turnover berpengaruh terhadap kondisi variabel Net Profit Margin. Jadi, hipotesis awal yang diajukan yaitu "Working Capital Turnover berpengaruh secara parsial terhadap Net Profit Margin perusahaan manufaktur yang terdaftar di Bursa Efek Indonesia Periode 2011-2015” diterima karena nilai signifikasi yang lebih kecildari 0,05 .

3. Secara parsial t hitung Debt Ratio diperoleh sebesar 1,301 yang lebih kecil dibandingkan dengan nilai $t$ tabel dan nilai signifikansi sebesar 0,200 lebih besar diatas 0,05. Hal ini menunjukkan bahwa perubahan yang terjadi pada variabel Debt Ratio tidak berpengaruh terhadap kondisi variabel Net Profit Margin. Jadi, hipotesis awal yang diajukan yaitu "Debt Ratio berpengaruh secara parsial terhadap Net Profit Margin perusahaan manufaktur yang terdaftar di Bursa Efek Indonesia Periode 2011-2015" ditolak karena nilai signifikasi yang lebih besar dari 0,05 .

\subsubsection{Hasil Uji F (Simultan)}

\begin{tabular}{|ll|r|r|r|r|r|}
\hline Model & & Sum of Squares & \multicolumn{1}{|c|}{ df } & Mean Square & F & Sig. \\
\hline \multirow{2}{*}{1} & Regression & 60,862 & 3 & 20,287 & 3,099 &, $036^{b}$ \\
& Residual & 301,138 & 46 & 6,546 & & \\
& Total & 362,000 & 49 & & & \\
\hline
\end{tabular}

a. Dependent Variable: Net Profit Margin

b. Predictors: (Constant), Debt Ratio, Current Ratio, Working Capital Turnover

Sumber : Data yang Diolah

Hasil uji simultan (uji f) menneujukkan nilai f hitung sebesar 3,099 lebih besar dibandingkan nilai $\mathrm{f}$ tabel sebesar 2,81 serta nilai signifikansi sebesar 0,036, hal ini menunjukkan bahwa variabel independen meliputi Current Ratio, Working Cpaital Turnover dan Debt Ratio secara bersama-sama berpengaruh terhadap variabel dependen Net Profit Margin.

\subsection{Koefesien Determinasi}

\begin{tabular}{|l|r|r|r|r|r|}
\hline Model & $\mathrm{R}$ & $\mathrm{R}$ Square & $\begin{array}{c}\text { Adjusted R } \\
\text { Square }\end{array}$ & $\begin{array}{c}\text { Std. Error of the } \\
\text { Estimate }\end{array}$ & Durbin-Watson \\
\hline 1 &, $410 \mathrm{a}$ &, 168 &, 114 & 2,559 & 1,495 \\
\hline
\end{tabular}
a. Predictors: (Constant), Debt Ratio, Current Ratio, Working Capital Turnover
b. Dependent Variable: Net Profit Margin

Sumber : Data yang Diolah

Nilai Adjusted R Square sebesar 0,114 atau 11,4\% variabel Net Profit Margin dipengaruhi oleh ketiga variabel independen (Current Ratio, Working Capital Turnover dan Debt Ratio) dalam model regresi ini, sedangkan sisinya sebesar $88,6 \%$ dipengaruhi oleh faktor lain di luar model. 


\section{KESIMPULAN DAN SARAN}

\subsection{Kesimpulan}

1. Berdasarkan hasil pengujian hipotesis 1 maka Current Ratio, Working Capital Turnover dan Debt Ratio berpengaruh secara simultan terhadap Net Profit Margin perusahaan manufaktur yang terdaftar di Bursa Efek Indonesia Periode 2011-2015.

2. Berdasarkan hasil pengujian hipotesis 2 maka Current Ratio tidak berpengaruh secara parsial terhadap Net Profit Margin perusahaan manufaktur yang terdaftar di Bursa Efek Indonesia Periode 2011-2015.

3. Berdasarkan hasil pengujian hipotesis 3 maka Working Capital Turnover berpengaruh secara parsial terhadap Net Profit Margin perusahaan manufaktur yang terdaftar di Bursa Efek Indonesia Periode 2011-2015.

4. Berdasarkan hasil pengujian hipotesis 4 maka Debt Ratio tidak berpengaruh secara parsial terhadap Net Profit Margin perusahaan manufaktur yang terdaftar di Bursa Efek Indonesia Periode 2011-2015.

\subsection{Saran}

1. Bagi para pemangku kepentingan baik internal maupun ekseternal penting untuk memperhatikan besaran Net Profit Margin maupun besaran nilai Current Ratio, Working Capital Turnover dan Debt Ratio sebelum melakukan aktivitas investasi maupun pengambilan kebijaan lainnya terkait dengan laju pertumbuhan perusahaan.

2. Bagi penelitian selanjutnya sebaiknya menambah variabel indpenden penelitian dengan variabel-variabel yang memiliki integrasi langsung terhadap aktivitas penjualan maupun pendapatan perusahaan. 


\section{DAFTAR PUSTAKA}

Anwar, Sanusi. 2011. Metodologi Penelitian Bisnis. Jakarta: Salemba Empat.

Arief, Elizar .2014. Analisis Pengaruh Non Performing Loan (NPL), Net Interest Margin (NIM), Beban Operasional Terhadap Pendapatan Operasional (BOPO), dan Loan To Deposit Ratio (LDR) Terhadap Capital Adequancy Ratio (CAR) (Studi Bank Umum Yang Terdaftar di Bursa Efek Indonesia Periode 2008-2012). Program Sarjana Fakultas Ekonomi dan Bisnis Universitas Makassar.

Arthur J. Keown, David F. Scott, Jr, John D. Martin, J. William Petty. 2008. Dasar-Dasar Manajemen Keuangan, Edisi Satu. Jakarta : Salemba Empat.

Arthur J.Keown,. 2005. Manajemen Keuangan:Prinsip dan Penerapan. Jakarta: Indeks.

Arikunto, S.. 2005. Manajemen Penelitian. Jakarta : Rineka Cipta.

Arikunto. 2010. Prosedur Penelitian: Suatu Pendekatan Praktek. Jakarta: Rineka Cipta.

Bastian dan Suhardjono. 2006. Akuntansi Perbankan. Edisi 1. Jakarta : Salemba. Empat.

Brigham, Eugene F dan Houston. 2006. Fundamental of FinancialManagement: Dasar-Dasar Manajemen Keuangan. Edisi 10. Jakarta: Salemba Empat.

Djarwanto. 2011. Pokok-Pokok Analisis Laporan Keuangan. Edisi Kedua. Yogyakarta : BPFE Yogyakarta.

Fahmi, Irham. 2013. Analisis Laporan Keuangan. Bandung: Alfabeta.

Ghozali, Imam. 2014. Structural Equation Modeling Metode Alternatif Dengan. Partial Least Squares (PLS). Edisi 4. Semarang : Badan Penerbit Universitas. Diponegoro.

Gitosudarmo, Indriyo. 2001. Manajemen Strategi. Yogyakarta: BPFE YOGYAKARTA.

Hery. 2014. Akuntansi Dasar 1 dan 2. Jakarta: Grasindo.

Harahap, Sofyan Syafri. 2001. Teori Akuntansi. Jakarta : Raja Gafindo Persada.

Harahap, Sofyan Syafri. 2006. Analisis Kritis Atas Laporan Keuangan. Jakarta: PT. Raja Grafindo Persada.

Harahap, Sofyan Syafri. 2011. Teori Akuntansi Edisi Revisi 2011. Jakarta: Rajawali Pers.

Hanafi, Mamduh H dan A. Halim. 2007. Analisis Laporan Keuangan, edisi 3. Yogyakarta : Penerbit UPP STIM YKPN.

Hanafi, Mamduh M dan Abdul Halim. 2009. Analisa Laporan Keuangan. Yogyakarta:

UPP STIM. YKPN.

Husnan, Suad., Enny Pudjiastuti, 2004. Dasar-Dasar Manajemen Keuangan. Edisi. Keempat. Yogyakarta : UPP AMP YKPN.

Kadir, Abdul. 2012. Analisis Faktor-Faktor Yang Mempengaruhi Net Profit Margin Perusahaan Manufaktur Yang Terdaftar pada Bursa Efek Indonesia. Jurnal 
Manajemen dan Akuntansi, April 2012 Vol 13 No 1.

Kasmir. 2008. Bank dan Lembaga Keuangan Lainnya. Edisi Revisi 2008. Jakarta: PT. Raja Grafindo Persaada.

Kasmir. 2009. Bank dan Lembaga Keuangan lainnya. EdisiRevisi 2008.

Jakarta. : Rajawali Pers.

Kasmir. 2012. Analisis Laporan Keuangan. Jakarta : PT. Raja Grafindo Persada.

Kasmir. 2013. Analisis Laporan Keuangan. Jakarta: PT Raja Grafindo Persada.

Kasmir. 2014. Analisis Laporan Keuangan. Edisi Satu. Cetakan Ketujuh. Jakarta : PT Raja Grafindo Persada.

K.R. Subramanyam dan John J. Wild (2010). Analisis Laporan Keuangan, Edisi. Sepuluh. Jakarta, Salemba Empat.

Munawir. 2001. Analisa Laporan Keuangan. Liberty: Yogyakarta. Rinati, Ina.

Munawir S. (2002). Analisis Laporan Keuangan. Yogyakarta: Liberty. Mudrajat

Munawir. 2004. Analisis Laporan Keuangan, Edisi Ke-4, Liberty, Yogyakarta. Ikatan Akuntansi Indonesia (IAI) Pernyataan Standar. Akuntansi Keuangan

(PSAK). Jakarta: Salemba Empat.

Raharjaputra. S. Hendra. 2009. Manajemen Keuangan dan Akuntansi. Jakarta:

Salemba Empat.

Riyanto, Bambang. 2013. Dasar-Dasar Pembelanjaan Perusahaan. Edisi. Keempat.

Yogyakarta : BPFE-Yogyakarta.

Sawir, Agnes. 2009. Analisa Kinerja Keuangan dan Perencanaan Keauangan Perusahaan. Jakarta : PT. Gramedia Pustaka Utama.

Soehartono, Irawan. 2004. Metode Penelitian Sosial. Bandung : PT. Remaja Rosdakarya.

Sugiyono. 2011. Metode Penelitian Kuantitatif, Kualitatif dan R\&D. Bandung: Afabeta.

Sutrisno. 2001. Manajemen Keuangan Teori, Konsep dan Aplikasi. Yogyakarta : Penerbit Ekonisia UII Yogyakarta.

Syahirman Yusi dan Umiyati Idris. 2009. Metodelogi Penelitian Ilmu Sosial. Pendekatan Kuantitatif. Jakarta : Citrabooks Indonesia.

Syamsuddin, Lukman. 2000. Manajemen Keuangan Perusahaan. Jakarta : PT Raja Grafindo Persada.

Syamsuddin, Lukman. 2009. Manajemen Keuangan Perusahaan. Jakarta: PT. Raja Grafindo. 